\title{
REFLECTION OF ANCIENT RELIGIOUS BELIEFS IN ANIMAL RITUALS (ON THE EXAMPLE OF JIZZAKH OASIS)
}

\author{
Khakima Babaydavlatovna Davlatova \\ Master student Methods of teaching social sciences and humanities (history) Jizzah State Pedagogical University \\ Uzbekistan
}

\section{ABSTRACT}

This article analyzes the fact that in the ancient Jizzakh oasis, animal husbandry was one of the most ancient forms of traditional farming and one of the main types of labor that determined the source of livelihood, and other issues. It also highlights the lifestyle of the herders and the views and traditions associated with this training, which have been studied to some extent by our research scientists on the basis of ethnographic materials, and similar issues.

KEYWORDS:- Jizzakh oasis, animals, traditional farming, livelihood, traditions, training, scientists, ethnographic materials, divine power, totemism, fetishism, paganism, Bronze Age, Central Asia.

\section{INTRODUCTION}

Although in ancient times people gave different names to the idea of divine strength, this power has always been considered God deciding their destiny. At various times, the tribes believed in "their" divine power, connecting their needs and desires, fears and joys with the divine power, and sought to understand the world. Trying to soften the savagery of nature with magic, they begin to worship its various manifestations - the Sun, the stars, the thunder, the rain, the wind, the fire. Thus, such beliefs as animism, totemism, fetishism, and paganism emerged, and their followers began to follow each other [Karamatov,
2008. P. 8].

Indeed, animal husbandry was one of the oldest forms of traditional farming and one of the main types of labor that determined the source of livelihood. The lifestyles of the herders and the views and traditions associated with this training have been studied to some extent by our research scientists on the basis of ethnographic materials. However, ancient religious ideas and beliefs related to animal husbandry have not yet been specifically studied as a separate object of study [Ashirov, 2007, PP. 145-146.]. After all, from ancient times, that is, since the beginning of the process of capturing and domesticating animals, the rituals and customs associated with 
CURRENT RESEARCH JOURNAL OF HISTORY 2(5): 17-20, May 2021

DOI: https://doi.org/10.37547/history-crjh-02-05-05

ISSN 2767-472X

(C)2021 Master Journals

Crossref doi 81 Google

Accepted 15th May, 2021 \& Published 20th May, 2021

animal husbandry reflected the attitude of the people to the animal world. At the same time, they embodied the relationship between man and nature, people and the animal kingdom, the life experiences and spiritual views of human society related to several thousand years of labor activity.

The economy of the population of Central Asia has long been based on natural and geographical features, and due to the first division of labor that took place in the Bronze Age, it was divided into a nomadic group engaged in agriculture, settlements and animal husbandry. In the Jizzakh oasis, along with agriculture, there were favorable conditions for livestock. The natural conditions of the oasis made it possible to raise all the cattle.

We know that from time immemorial in Ustrushna, along with the peasant population, livestock breeders also played an important role in the growth of the population around agricultural oases, the development of new lands and turning them into prosperous agricultural oases. In the cultural life of the peoples of the region, the coexistence and intermingling of the two types of farms have played an important role. The ancient spiritual and religious ideas of the Ustrushona herdsmen came in different forms [Toshboev, 2018, P. 37].

Sources mention the pre-Islamic pastoral beliefs of the Turkic tribes in various forms of shamanism (ancestor spirits, Blue God) and religious rites associated with totemistic views (worship of animals, mountains, water sources rivers and lakes). One of the most common religious beliefs in ancient times was shamanism. This religion nurtured the spirit of faith in souls and spirits and created the universe from nothingness - based on the worship of the Blue God.

\section{Materials AND METHODS}

In the mountains of Turkestan (Morguzar) passing through the oasis, in the Uriklisay gorge, there is a huge $(5 \times 3 \mathrm{~m})$ shaman-stone god (Tangri sang) facing east (sunrise) from the mountain rock [Alibekov., Nishanov, 1978. P.97]. Naturally, this image of the shaman, resembling the head of a man in Turkish appearance, was a sacred place of worship for the cattle-breeding population. This monument testifies to the widespread perception of Shamanism among the cattle-breeding population of Ustrushona.

In addition to the livestock breeders in the oasis, animal husbandry also played an important role in the life of the farming population. Farmers used them mainly as a source of labor, livestock, auxiliary power, and additional income. There was a nature and purpose of the rites and customs of animal husbandry, that is, the rites were aimed at the reproduction of the animal, its protection from various diseases, wild beasts, and thieves. This means that pet health has always been important for breeders. They performed various rituals at certain times of the year to protect the animal from various calamities, evil forces, evil eyes and attacks of wild animals [Ashirov, 2007. P. 147.].

As a result of research carried out by the archaeologist F.E. Toshbaev at the Gulbo cemetery in the Zaamin district, objects such as arrows, bows and arrows were found. According to the researcher, they also have widespread views about Umay mother.

\section{RESULTS AND DISCUSSION}

Mother Umay symbols are known to include many household items, including a lover, a bow and arrow, a brass button, and a urchuk, along with items such as the umbilical cord. In ancient times, religion developed through the worship of 
CURRENT RESEARCH JOURNAL OF HISTORY 2(5): 17-20, May 2021

DOI: https://doi.org/10.37547/history-crjh-02-05-05

ISSN 2767-472X

(C)2021 Master Journals

\section{Crossref dof 81 Google}

Accepted 15th May, 2021 \& Published 20 th May, 2021

nature, and some processes and things in existence were understood as girls, women. Umay is a hero of the ancient cattle-breeding Turkic peoples, a protective helper of the hero. Mahmud Kashgari uses the word "Umay" in the lexical sense of "companion". He also explains that Umay is something that comes out of the belly of young, tear-stained women, and that the child is a companion in the womb. The proverb "If you worship Umay, you will have a son" is common among the ancient Turkic peoples, he writes that there is a myth that a son will be born [Jumabekov., Alikulov, 1999, P. 72]. It is obvious that in the ancient Turkic peoples Umay-Mother was considered on the one hand as a source of worship of heroes in the war, and on the other hand as a caregiver of young children, a companion of the child in the womb and in the postpartum period. Toshboev, 2018, P. 38.]. So, the sexes in the human imagination - most of the spirits (grandmothers, fairies) are named after women. These traditions have very ancient roots and are widespread among breeders and passed down from generation to generation.

\section{Conclusion}

In a conclusion, one of the urgent tasks today is an in-depth study of the ancient culture of the Uzbek people, traditions and rituals aimed at the rational use of nature, to convey its essence to the general public. At the same time, it is necessary to study the views of our ancestors on the preservation of nature, ancient religious values that reflect the harmony of man and nature, and bring them to the attention of the general public. This will help to study the traces of ancient religious beliefs in the traditional life of the Uzbek people on the example of the Jizzakh oasis, and in a sense to understand the essence of the rituals and customs. Our scientific research and studies will help us restore some of the forgotten rituals in the oasis as cultural heritage.

\section{ReFERENCES}

1. Karamatov H. History of religious beliefs in Uzbekistan. Tashkent:, 2008.

2. Ashirov A. Ancient beliefs and ceremonies of the Uzbek people. Tashkent: "Publishing House of the National Library of Uzbekistan named after Alisher Navoi",2007.

3. Toshboev F. On the pre-Islamic religious beliefs of the Ustrushona herdsmen. // Lessons of Imam Bukhari //. Issue 2 of 2018.

4. Alibekov L.A., Nishanov C.A. Natural conditions and resources of Djizak region. Tashkent: “Uzbekistan”,1978.

5. Jumabekov A., Aliqulov R. The concept of Umay mother in the ancient Turkic peoples. Samarkand, 1999.

6. Jizzakh Tourist internet sites.

7. DAVLATOVA, K., \& NEMATOV, O. (2021). Tajiks of jizzakh oasis: traditional way of life, customs and traditions and rituals. Journal of Contemporary Issues in Business and Government, 27(3), 1324-1329.

8. Jumanazarova, D., \& Davlatova, H. (2021). Customs of Population In Jizzakh Oasis Associated With Chilla. The American Journal of Interdisciplinary Innovations and Research, 3(04), 63-66.

9. Khakima, D. (2021). Customs Related To Tadjiks' Wedding In Jizzakh Oasis. The American Journal of Political Science Law and Criminology, 3(04), 38-41.

10. Davlatova, K. Opportunities and Prospects for the Development of Ecotourism in the Jizzakh Oasis.

11. Неъматов Озодбек Неъматович , \& 
CURRENT RESEARCH JOURNAL OF HISTORY 2(5): 17-20, May 2021

DOI: https://doi.org/10.37547/history-crjh-02-05-05

ISSN 2767-472X

(C)2021 Master Journals

Crosser do) 818 Google

Accepted 15th May, 2021 \& Published 20 th May, 2021

Муяссаров Бегали Қосимжон Ўғли (2020).

Шахс маънавиятини юксалтиришда

инновацион технологияларнинг

методологик жихатлари. Science and

Education, 1 (1), 296-303.

12. Юнусова, Х. Э. (2013). НЕКОТОРЫЕ

ВОПРОСЫ ИЗУЧЕНИЯ РЕПРЕССИЙ В

УЗБЕКИСТАНЕ ПО «ХЛОПКОВОМУ ДЕЛУ».

ББК 72 С56, 124.

13. Ozodbek, N., Tolipov, F., \& Yunusova, X. (2019). Historical and ethnographic features of the Uzbek Kurash. International Journal of Recent Technology and Engineering, 8(2 Special Issue 3), 1614-1616. 